\title{
DEVELOPMENT OF SCIENTIFIC OPINION ON THE FORMATION OF NATURAL RESOURCES LAW
}

\author{
Yermolenko V. M., Deineha M. A., Kostytska I. O.
}

\section{INTRODUCTION}

At the turn of the millennium, the priority for the further development of civilization is the harmonization of interactions between society and nature. However, the environmental situation continues to deteriorate, creating a real threat to humanity's existence, and the unrestrained pursuit of economic growth turns to the destruction of natural resource potential. The intensive development of scientific and technological progress has led to the emergence of a number of global environmental problems, each of which is capable of threatening the destruction of civilization.

The need to find an acceptable balance in the relationship between society and nature requires the consolidation of actions of the whole world community aimed at providing a favorable environment with increasing rates of exploitation of natural resources, enhancing anthropogenic impact on the environment. A necessary factor in changing approaches to the use of natural resources has been the transition to a sustainable development strategy, the essence of which is to improve human well-being and strengthen social justice while reducing the risks to the environment and the scarcity of natural resources.

At the same time, addressing environmental issues and socio-economic development is now one of the main activities of any civilized state. Before every country in the world there is a dilemma - how to combine the interests of nature conservation with the interests of economic and social development, how to ensure a systematic consideration of environmental and economic interests, which is a condition for sustainable development as a new paradigm of interaction between society and nature. Ukraine is no exception.

Our country has a strong potential for ecosystem, landscape and species diversity, and at the same time belongs to a group of countries with complex environmental problems. The imbalanced and exhausting use of natural resources is typical of both developing and industrialized countries. The economic growth, that all countries seek and which society expects, will inevitably lead to increased use of natural resources, which in turn increases the anthropogenic burden on the quantitative and qualitative state of natural resources. Existing land-use practices are causing the deterioration of land, and the irrational use of land, forest and water resources leads to irreversible loss of ecosystems and biological diversity. 
Nowadays there is an urgent need to introduce a system of sustainable, environmentally balanced use of natural resources in our country. First of all this implies a change in approaches to their use, taking into account the negative consequences of human interference in the course of natural processes and the balance of interests of development of society and nature. An important role in the process of implementing environmentally balanced use of natural resources will have a natural resource right formed on the basic principles of the concept of sustainable use and conservation of natural resources.

The study of the genesis of scientific thought on the formation of any legal phenomenon helps to uncover the origins and further development of certain social relations that are the object of study, as well as to assess the correctness or error of the mechanism of legal regulation of social relations over a certain time. In this regard, the problematic issues raised are of sufficient scientific interest because it enables one to understand the legal nature of the studied social relations, as well as to find out the place of natural resource law in the system of law and legal doctrine.

The work of such prominent representatives of domestic and foreign legal science, as: V.I. Andreytsev, Yu.O. Vovk, A.P. Hetman, V.M. Yermolenko, B.V. Erofeev, V.A. Zuev, M.D. Kazantsev, I.B. Kalinin, I.I. Karakash, O.S. Kolbasov, V.V. Kostytsky, M.V. Krasnova, P.F. Kulinich, N.R. Malysheva, V.V. Petrov, V.K. Popov, M.V. Shulga and other scientists. However, recognizing the autonomy of natural resource law and determining its place in the legal system remains an urgent problem today.

\section{Formation of natural resources law as an integrated branch of law}

Initially, the subject of environmental law developed within the differentiated (resource) approach to environmental management. At the first stage, the relations that were formed about the use of certain natural resources, especially land, forest and subsoil relations, were subjected to legal regulation. And only in the middle of XX century as a result of society's awareness of global and national problems in the use of natural resources, pollution and degradation of the environment, increasing negative impact on human health, an integrated, ecosystem approach in the field of environmental management has emerged ${ }^{1}$.

The rules governing natural resources relations can be found in the Russian Pravda, the Code of Laws of the Russian Empire, but by the beginning of the XX century as such a system of environmental legislation did

${ }^{1}$ Deineha M.A. Development of scientific thought on the formation of natural resources law. Scientific Bulletin of Uzhgorod National University. 2018. Issue No 49. P. 9. 
not exist. In the early twentieth century resource branches of law (land, forestry, water, subsoil law, etc.) were regarded as separate branches (apparently, to the extent of the general conceptions of the branches of law that existed in those years). Legal norms aimed at regulating the use and protection of natural resources were contained in decrees of the Soviet government "On the socialization of land" (1918), "On the bowels of the earth" (1920), "On forests" (1923), etc. Adoption of the Land and Forest Codes of the USSR was of great importance for regulating resource relations. At that time, there was also no question of natural resource law.

In the 30's of XX century independence of the resource branches of law began to be challenged, since the theory of a unified land-collective farm law prevailed. After obtaining the land right of independence in the 1940s other resource industries began to be incorporated into land law in its "broad sense" . Land law was interpreted as a set of legal norms aimed at regulating not only land, but also mountain, forest, water and other relations related to the use and protection of natural resources ${ }^{3}$.

In fact, land law was, in a broad sense, a prototype of natural resource law, the idea of which was later in the 1960s. put forward M.D. Kazantsev ${ }^{4}$, later supported by leading legal scholars: Yu.O. Vovk, B.V. Erofeev, V.V. Petrov, V.K. Popov, Yu.I. Tyutekin ${ }^{5}$.

M.D. Kazantsev argued that the differentiation of the branches of law governing relations regarding the use and protection of natural resources poses the problem of integration of these branches and the formation of natural resource law ${ }^{6}$. At the same time, the resource branches of law and environmental law, while maintaining their autonomy as branches of law, in the generally accepted sense of the term, form a special part of nature law as an integrated branch of law. The scientist has determined that the natural

\footnotetext{
${ }^{2}$ Kolbasov O.S. Ecology: politics - law. Legal protection of nature in the USSR. Moscow: Science, 1976. P. 147.

${ }^{3}$ Kolbasov O.S. Ecology: politics - law. Legal protection of nature in the USSR. Moscow: Science, 1976. 148 p.

${ }^{4}$ Kazantsev N.D. Natural resources law and its limits as an integrated sector. Bulletin of the Moscow University. 1967. № 6. P. 9.

${ }^{5}$ Vovk Yu.A. Soviet environmental law and environmental protection. The common part: a study guide. Kharkiv: High School, 1986. 317 p.; Erofeev B.V. Soviet natural resource law. Moscow: Law. 283 p.; Popov V.K. Soviet natural resource law and legal environmental protection. A common part. Popov V.K., Vovk Yu.A. and other. Kharkov: Publishing house Khark. state University, 1988. 372 p;. Natural resource law and legal environmental protection / ed. V.V. Petrova. Moscow: Jurid. lit., 1988. 421 p.; Tyutekin Yu.I. Nature, society, law. Chisinau, 1971. P. 219.

${ }^{6}$ Kazantsev N.D. Natural resources law and its limits as an integrated sector. Bulletin of the Moscow University. 1967. № 6. P. 9.
} 
resource right should become a super industry ${ }^{7}$. Yu.I. Tutekin acknowledged the existence of an integrated comprehensive branch of law, but denied the existence of such an integral part as environmental law ${ }^{8}$.

On the advanced theory of M.D. Kazantsev, M.T. Osipov pointed to the "undoubted merit" of a scientist to find a new approach to the problem of improving the effectiveness of the legal regulation of relations, whose objects are land, subsoil, forests, water and other natural resources ${ }^{9}$. At the same time A.S. Kolbasov criticized the position of M.D. Kazantsev. According to the scientist, these statements are of value in themselves only if they are supported by a specific analysis of the content of the proposed branches of law ${ }^{10}$.

At that time, all the attempts of M.D. Kazantsev's withdrawal of the system and structure of natural resource law was reduced to almost the already defined concept of land law in a broad sense.

However, Yu.O. Vovk believed that the existence of the field of natural resource law was obvious ${ }^{11}$. Its subject matter is a kind of public relations regarding the rational use and protection of natural resources. This subject, as noted by the scientist, is unique because of the unity and inseparable connection of all natural resources, as well as the general principles of nature management. At the same time, it is multifaceted, which is reflected in the subspecific diversity of the relations under consideration, caused by different kinds of natural resources, about which there are social relations ${ }^{12}$.

V.V. Petrov pointed out that natural resource law functions in the ecological and legal structure of law together with environmental law and individual legal institutions, legal norms that are part of various branches of law and implement within the regulated relations ecological and legal functions ${ }^{13}$. At the same time, the scientist pointed out that environmental law, unlike the natural resource, which has nature protection sections, regulates the protection of the natural environment in the complex and the unity of its interconnections ${ }^{14}$. V.V. Petrov also supported the idea of independence of natural resource law.

\footnotetext{
${ }^{7}$ The same, p. 8 .

${ }^{8}$ Tyutekin Yu.I. Nature, society, law. Chisinau, 1971. P. 127.

${ }^{9}$ Osipov N.T. Theoretical problems of Soviet land law. Leningrad: Publishing House of Leningrad State University, 1975. P. 21.

${ }^{10}$ Kolbasov O.S. Ecology: politics - law. Legal protection of nature in the USSR. Moscow: Science, 1976. P. 74.

${ }^{11}$ Vovk Yu.A. Soviet environmental law and environmental protection. The common part: a study guide. Kharkiv: High School, 1986. P. 317.

${ }^{12}$ The same, p. 10.

${ }^{13}$ Petrov V.V. Ecology and law. Moscow: "Legal literature", 1981. P. 47.

${ }^{14}$ Legal protection of nature / ed. V.V. Petrova. Moscow, 1980. P. 29.
} 
The design of the integrated mono-branch of natural resource law was proposed by N.B. Mukhitdinov, the main task of which, as noted by the scientist, should be a comprehensive regulation of the most common and important issues of protection and use of natural resources ${ }^{15}$. According to the scientist, overhead, forest, water and land law are correlated with natural resource law as equal, independent elements of a unified system of law ${ }^{16}$. He supported the idea of forming an independent branch of natural resource law and N.T. Razgeldeev ${ }^{17}$.

Thus, based on the scientific idea of M.D. Kazantsev, in the 60-80's of the $\mathrm{XX}$ century. the integrated legal branch - the natural resource law - was formed.

\section{Development of natural resources law in the system of environmental law}

The growing role of environmental social relations in the early 1990s, changes in the political system and related socio-economic and legal processes have adjusted the direction of the development of scientific thought on the formation of natural resource law. These factors, as well as the global ecological crisis and the response of the world community to environmental problems, actually led to the formation of a new position in the development of public relations regarding the use of natural resources and environmental protection - the theory of environmental law, introduced in 1987 by V.V. Petrov ${ }^{18}$. In the system of interaction between society and nature, as noted by the scientist, significant changes have taken place, which led to the strengthening of the consolidation of resource and security relations on the basis of common ecological relations ${ }^{19}$. V.V. Petrov stated as a result of the emergence of a new branch of law - environmental law, on the basis of the consolidation of the natural resource and environmental law.

About this B.V. Erofeev noted that natural resource law is more selfish about the environment than environmental law, which also regulates consumer relations of society, but directs them in such a way that they do not harm the environment as a system of environmental ties, so the objective need

${ }^{15}$ Mukhitdinov N.B. Fundamentals of mountain law: Some important points of theory and practice. Alma-Ata, 1983. P. 136.

${ }^{16}$ The same, p. 137.

${ }^{17}$ Razgeldeev N.T. Responsibility under the Soviet environmental law. Saratov: Publishing house of Sarat. University, 1986. P. 198.

${ }_{18}$ Petrov V.V. The concept of environmental law as a legal community, science and academic discipline. Bulletin of Moscow University. Series 11. Law. 1987. No 5. P. 34-39.

${ }^{19}$ The same, p. 35. 
for social development in modern times the stage is the fastest possible transformation of environmental legislation into environmental law ${ }^{20}$.

From the 90's of the XX century in the field of environmental law on the basis of integration and differentiation formed three basic doctrines of substantive substantiation of environmental law: a) identification with environmental law, which includes two groups of legal relations - rational environmental management and environmental law; b) an integrated supersector with sectoral and sub-sectoral subsystems with three spheres of legal regulation: natural resource; environment protection, landscape; legal support for environmental safety; c) the concept of a comprehensive branch of law that integrates the legal rules governing systematic environmental relations for the protection of life and health of citizens, protection of their environmental rights and freedoms, rational use of the environment and quality of the environment for the benefit of modern and future generations; d) independent differentiated legal branch ${ }^{21}$.

The founder of the theory of environmental law as an integrated, integrated field of law is Yu.S. Shemshuchenko ${ }^{22}$. The scientist defined environmental law as an independent complex branch of law, which is a set of internally interconnected legal norms that regulate environmental social relations in order to implement the state policy in the field of environmental protection and rational use of natural resources, creating favorable environmental conditions for the current and future generations of people ${ }^{23}$. In this case, according to Yu.S. Shemshuchenko, scientifically unconvincing and practically futile, are attempts to prove the existence of two independent integrated branches of law - nature conservation and nature resource law.

The same opinion is followed by N.R. Malysheva. As the scientist points out, natural resource law is a structural part of the complex field of environmental law, as well as land, water, subsoil, forest and faunistic, which in turn are components of natural resource law ${ }^{24}$.

An integrated approach in defining the concept of environmental law is applied by V.I. Andreytsev. According to the scientist, it is an integrated legal community that integrates a set of ecological and legal norms governing ecological relations for the effective use, reproduction, protection of natural

\footnotetext{
${ }^{20}$ Erofeev B.V. Environmental law: textbook. Moscow: The New Lawyer, 1998. P. 87.

21 Deineha M.A. Problems of formation of natural resources law. Scientific Bulletin of the National University of Life and Environmental Sciences of Ukraine: Law series / ed.: S.M. Nikolaenko (chairman) and others. Kyiv, 2015. Vol. 232. P. 60.

${ }^{22}$ Shemshuchenko Yu.S. Legal problems of ecology. Kiev: Naukova Dumka, 1989. P. 206.

${ }^{23}$ The same, p. 64.

${ }^{24}$ Malysheva N., Nepyvoda V. Correlation of natural resource law and environmental law: a new look at the old problem. State and Law. No. 9. 2007. P. 36.
} 
resources, environmental quality assurance, guarantee of ecological safety, realization of protection of environmental rights ${ }^{25}$. V.I. Andreytsev attributes environmental law to an integrated super-industry with sectoral and subsectoral subsystems, aimed at regulating the efficient use of natural resources (environmental resources), ensuring the quality of the environment (environmental relations), safety for life and environmental health (anthropological).

From domestic scientists, a similar opinion was expressed and continues to defend V.V. Kostytsky ${ }^{26}$.

Similar views on the integrated structure of environmental law are expressed by foreign scholars ${ }^{27}$. According to them, environmental law consists of three parts: environmental law and environmental law, as well as environmental protection requirements and environmental rules of law in other branches of law.

The concept of complex regulation of ecological-legal relations is adhered to by M.V. Krasnova, which defines environmental law as a public-law branch, which is based on the legal protection of public interests related to non-property benefits, in particular the interests of the Ukrainian people to realize the right of ownership of natural resources as national wealth, the right to safe and quality natural environment, rights to environmental well-being ${ }^{28}$. On the structure of domestic environmental law as a complex legal branch, according to Y.S. Shemshuchenko, four groups of social relations are crucial: relations with regard to environmental protection; relations on the use of natural resources; relations on ensuring environmental safety; relations concerning the formation, conservation and rational use of the ecological network ${ }^{29}$.

M.V. Shulga views environmental law as an independent (not complex) branch of law with a sub-sectoral structure. The scientist emphasizes that such an approach preserves the integrative unity and species differentiation of environmental law, which is caused by the unity and features of land, water, subsoil, faunistic, atmospheric-air and other varieties of social relations. According to the scientist, the essence of the unity of these relations is that they arise, are effected and terminated in relation to certain natural objects that develop

${ }^{25}$ Andreytsev V.I. Environmental law. General: Lecture Course in Schemes: Tutorial. Kyiv: Venturi, 1996. P. 18.

${ }^{26}$ Kostytsky V.V. Environmental law: textbook. Drohobych: The Circle, 2012. P. 77.

${ }^{27}$ Pankratov I.F. Improving environmental and land law in modern conditions: materials of a scientific and practical conference. State and law. 1996. No. 5. P. 14.

${ }^{28}$ Krasnova M.V. Methodological principles of modern environmental law. Bulletin of Taras Shevchenko National University. Law. 2012. № 92. P. 8.

${ }^{29}$ Environmental Law of Ukraine. Academic course: textbook / ed. Yu.S. Shemshuchenko. 2nd edition. Kyiv: Legal Opinion, 2008. P. 15. 
according to the relevant laws of nature. And all natural objects are collectively interconnected, forming a single ecological system. It is this system that is the objective basis for the existence of a unified environmental relationship. The objectively existing unity of ecological relations is the basis for the corresponding unity of legislation on the regulation of nature management and environmental protection. These relationships are based not only on the social appraisal of specific natural resources and the specific features of their use that result from such appraisal, but also take into account the properties of natural objects, patterns of existence and development of a single nature.

Representatives of the Kharkiv Ecological Law School, led by A.P. Hetman: "the most reasoned is the opinion of those authors who consider environmental law as an independent (non-complex) branch of law with a sub-sectoral structure" 30 .

Recognition in the late 80's of the twentieth century environmental law an independent branch of law and formation in the early 90's of the twentieth century. modern environmental law has been strongly influenced by the more than seventy years of application of the Soviet public-law dogma in the area of legal regulation of the use of natural resources and environmental protection. The Soviet period of development of law practically neutralized the principles of private law in the field of environmental management.

It was during this period that the legal regulation of the use of natural resources and the environment was fundamentally at odds with the development of similar legal mechanisms abroad. If the environmental and environmental law of Europe and the US during the XX century gradually creating more and more compromises in the combination of private law and public law (gradually moving to their parity), then the legal regulation of environmental management in the Soviet period was linked solely to the public legal framework.

However, relations regarding the use of natural resources deserve an independent specific legal regulation, which nowadays can no longer be guaranteed by environmental law. In today's context, it is unnecessary to include these relationships in the context of environmental ones, since the natural resource approach to their regulation cannot be ignored. In this regard, Yu.A. Krasnova emphasizes the need for legal regulation of public relations regarding the use of natural resources, which is due to the interest of society in their detailed regulation, taking into account the specificity of each object ${ }^{31}$.

\footnotetext{
${ }^{30}$ Environmental Law: textbook / ed. A.P. Hetman. Kharkiv: Law, 2013. P. 15.

${ }^{31}$ Krasnova Yu.A. Problems of integration and differentiation in environmental law: the issue of the formation of environmental security law. Problems of integration and differentiation in environmental law: materials of the Round Table (Dnipropetrovsk, September 25, 2014). P. 146.
} 


\section{Establishment of natural resource law as an independent branch of law}

The emergence of the concept of natural resource law as an independent branch of law in the system of law of independent Ukraine belongs to the creative achievement of I.I. Karakash ${ }^{32}$. The scientist notes that such sufficiently developed and widely recognized in the law the natural resource and nature protection social relations cannot be combined within a single branch of law and integrated legal regulation ${ }^{33}$. The scientist draws attention to the untimely integration of these social relations.

I.I. Karakash points out that the positive result of the formation of the natural resource law was the impetus to the development of branches of the domestic resource legislation of the independent Ukrainian state - radical reformation and revival of land law, significant renewal of water, forest and subsoil law, as well as the formation of faunistic ${ }^{34}$. That is why natural resource law in the long run should really claim to play a fundamental branch of law in the Ukrainian legal system.

Natural resources relations, as noted by I.I. Karakash are complex in that they combine land, subsoil, water and forest relations, as well as relations regarding the use of fauna and flora and other natural resources, leaving the specifics of legal regulation of their use within the respective differentiated branches of resource legislation ${ }^{35}$. This complex of relations is formed on the basis of integration only common in content of land, subsoil, water, forest and other natural resources relations. According to the scientist, natural resource law in the Ukrainian legal system is a separate and complex set of legal rules governing resource relations in order to ensure the rational use of natural objects and their resources, as well as their timely and effective reproduction $^{36}$.

Similar views are shared by other scholars, albeit from different scientific positions and justifications. However, the completeness of natural resource law as an independent branch of law does not cause any doubt to any of these scientists.

Thus, V.M. Yermolenko points out that the environmental-legal doctrine artificially attracted environmental law at the level of the structural

${ }^{32}$ Natural resources law of Ukraine: textbook / ed. I.I. Karakash. Kiev: The Truth, 2005. P. 376.

${ }^{33}$ Karakash I.I. The subject and system of natural resource law. Natural resources law of Ukraine: textbook / ed. I.I. Karakash. Kiev: Truth, 2005. P. 14.

${ }^{34}$ The same.

35 Karakash I.I. On the differentiated and integrated concept of natural resources and environmental law. Problems of integration and differentiation in environmental law: materials of the round table (Dnipropetrovsk, September 25, 2014). Dnepropetrovsk: NSU, 2014. P. 88.

${ }^{36}$ The same. 
component $^{37}$. At the same time, as the scientist points out, nowadays natural resource law must be recognized as an independent branch of law, which unites the rules of law, which determine the general principles of establishing the ownership of natural resources, forms and methods of rational use of nature, the procedure for granting permits for special nature use, features of the process restoration of disturbed natural resources and the like. These rules, according to V.M. Yermolenko, will represent in the classical sense a common part for each of the existing resource sectors ${ }^{38}$.

Foreign scientists also uphold the concept of independence of natural resource law. I.B. Kalinin points out that from the very beginning of the formation of natural resource law as an independent branch, environmental (environmental) law was included in its subject, since historically the use of natural resources began much earlier than the need for their protection arose ${ }^{39}$. The scientist regards natural resource law as an independent branch of law, the subject of which is a set of relations related to the extraction of natural resources. Within the framework of such relations, the scientist distinguishes the so-called: 1) resource (relations concerning the direct extraction of natural resources from the environment of their finding, as well as their related relations with search, evaluation, exploration); 2) relationships that are closely related to the resource: relationships that precede the resource; relations on the safety and rationalization of environmental management; ownership of natural resources; public resource management relations; relations concerning the holding of subjects of natural resources right to account and for the consideration of disputes arising from the use of natural resources and compensation for the harm caused by their misuse ${ }^{40}$. G.V. Chubukov draws attention to the fact that the substantive characteristic of the natural resource law is determined by: the presence of specific natural resource relations, which are related to the satisfaction of vital human needs at the expense of natural benefits; the peculiarities of the object of legal regulation on which legal rules are drawn up ${ }^{41}$.

37 Yermolenko V.M. Natural resources law in the system of law of Ukraine. Natural Resources Law in the Law System of Ukraine: History, Present, Prospects: Collection of Round Table Materials (Kharkiv, October 30-31, 2015) / ed. M.V. Shulga. Kharkiv: Yaroslav the Wise National Law University, 2015. P. 88.

${ }^{38}$ Yermolenko V.M. Theoretical problems of differentiation of branches of environmental and natural resources law. Law of Ukraine. 2010. № 6. P. 148.

${ }^{39}$ Kalinin I.B. Natural resource law: training manual. Tomsk: Publishing House Tom. University, 2009. P. 82.

${ }^{40}$ The same, p. 112.

${ }^{41}$ Kalinin I.B. Natural resource law: training manual. Tomsk: Publishing House Tom. University, 2009. P. 6. 
Recognizing the independence of natural resource law, Belarusian scientists characterize it as a complex branch of law, which is a set of legal norms that regulate social relations between people in the process of environmental management to meet the socio-economic needs and in general the development of the state ${ }^{42}$.

So, at the beginning of the XXI century on the basis of scientific ideas I.I. Karakash formed the concept of independence of natural resources law, which has found support among domestic and foreign scientists. At the same time, neither the priority development of environmental law with the integration into its structure of natural resources relations, nor the strengthening of greening of resource industries in modern conditions should not deny the need to form and become a branch of natural resources law in the system of law of independent Ukraine.

The legal nature of natural resource relations is the subject of research and outstanding scientists of ecological and legal doctrine - supporters of the opposite scientific position. V.I. Andreytsev points out that natural resource relations consist mainly of the use and restoration of specific natural resources as the main means of management, production and conditions of human life, to meet the spiritual, material, therapeutic, aesthetic, recreational, cultural and educational needs and other needs ${ }^{43}$. P.F. Kulinich defines natural resource relations as a set of complex social relations regarding the use and reproduction of certain natural resources in their inextricable connection with other elements of the environment ${ }^{44}$.

At the same time, in VI's view Andreytseva, to speak about natural resource law as an independent branch of law is nothing but to distort the objects of this right, which will lead to rupture of their dialectical unity with landscapes and natural complexes, ensuring safe conditions of conservation and protection, including prevention of negative impact on the human life environment. Therefore, according to the scientist, the greatest social, economic, environmental effect can be achieved in a harmonious combination of natural resources and other components of the sphere of life (biosphere) while ensuring and solving all problems of sustainable development ${ }^{45}$.

42 Markina N.A. Natural resource law: lecture course. Vitebsk: VSU named after P.M. Masherova, 2017. P. 6.

${ }^{43}$ Andreytsev V.I. Environmental law. General: Lecture Course in Schemes: Tutorial. Kyiv: Venturi, 1996. P. 97.

${ }^{44}$ Kulinich P.F. Natural law as a legal phenomenon: polemical aspects. Natural Resources Law in the Law System of Ukraine: History, Present, Perspectives: Collection of Round Table Materials (Kharkiv, October 30-31, 2015) / in total. ed. M.V. Shulga. Kharkov: Issue of Oberg Ltd., 2015. P. 152.

${ }^{45}$ Andreytsev V.I. Prospects for the development of natural resource law in the system of environmental law of Ukraine. Natural Resources Law in the Law System of Ukraine: History, 
P.F. Kulinich points out that the idea of natural resource law has not reached the level of scientific theory in its development, remaining a scientific hypothesis, which is not confirmed by practice. According to the scientist, this is due to the absence of the subject of natural resource law - a clear, "sensitive" to the legal influence of the system of social relations, which could be qualified as natural resources relations ${ }^{46}$.

M.V. Krasnova, not recognizing natural resource law as an independent branch of law, characterizes it as: a generic term that is used to refer to a group of branches of law having a common subject, namely: legal relations in the use, protection and reproduction of natural resources; the field of legal science and relevant scientific specialty; a discipline that was taught predominantly in higher education in the $1980 \mathrm{~s}^{47}$.

Indeed, most well-known scientists do not share the aforementioned approaches to the development of environmental law outside of environmental law, but in so doing, giving environmental law almost the most important place in the environmental law system. This scientific debate on finding out the place and legal affiliation of natural resources relations, recognizing the independence of natural resources law in the legal system dates back more than half a century and is still an urgent issue.

The current stage of development of natural resource law is characterized by the lack of a generally recognized approach to determining its place in the system of law. From the very beginning of the establishment of natural resource law as an independent branch, environmental law was included in its subject, since historically the use of natural resources began much earlier than the need for their protection arose. Therefore, at the stages of the formation of environmental law it seemed natural to include environmental relations in the subject of legal regulation.

In the future, scientific literature has suggested that environmental law has outgrown the natural resource framework, since it has the task of protecting not only a particular natural resource but also nature as a whole. The obvious link between the use and protection of natural resources has led to the incorporation of environmental law into environmental law

\footnotetext{
Present, Prospects: Collection of Round Table Materials (Kharkiv, October 30-31, 2015) / ed. M.V. Shulga. Kharkiv: Yaroslav the Wise National Law University, 2015. P. 10.

${ }^{46}$ Kulinich P.F. Natural law as a legal phenomenon: polemical aspects. Natural Resources Law in the Law System of Ukraine: History, Present, Perspectives: Collection of Round Table Materials (Kharkiv, October 30-31, 2015) / in total. ed. M.V. Shulga. Kharkov: Issue of Oberg Ltd., 2015. P. 154.

${ }^{47}$ Krasnova M.V. Modern realities of the natural resource law of Ukraine. Natural Resources Law in the Law System of Ukraine: History, Present, Prospects: Collection of Round Table Materials (Kharkiv, October 30-31, 2015) / ed. M.V. Shulga. Kharkiv: Yaroslav the Wise National Law University, 2015. P. 143.
} 
(environmental law), or as a sub-branch, or as a collection of individual sub-sectors (water, forest, subsoil, faunistic, etc.).

Mechanical movement of the set of rules governing public relations on the use of natural resources from one branch of law to another, did not change, and could not change the nature and specifics of natural resource relations, turn relations on the use of natural resource in relations with its protection. The content of natural resource relations as a public relation to the use of natural resources and related relations has not changed for many centuries and is independent of the content of conservation activities. Natural resource relations consist of the use and reproduction of natural resources or their properties (for example, the potential energy of water, which is converted into electricity, the surface of water for water transport, the properties of atmospheric air to accommodate and dissolve (reduce concentration) pollutants, the property of subsoil in underground gas storage, etc.), and environmental relations are aimed at protecting the natural object or the environment as a whole and are not relevant as many natural objects as the internal and external relations of these objects, their properties, states and processes occurring in them.

Therefore, the subject of legal regulation of natural resources law should be considered public relations on the use and reproduction of natural resources as a legally defined part of the environment, which has signs of natural origin and is in ecological connection with other natural resources, potentially or actually valuable for humanity, used or can be used as a source of material and spiritual benefits ${ }^{48}$. In this case, natural resource relations are complex in nature, because they unite in their content land, water, forest, subsoil and other relations, defining the general principles of their legal regulation, while leaving the specific legal regulation of the use and reproduction of certain natural resources within the relevant resources. areas of law (land, water, forest, etc.).

The subject matter of the law is that any set of social relations must be a systemic phenomenon, based on objective systemic factors and links that unite the various social relations. The unity of the field of environmental law is due to the presence of systemic factors, which include the subject, object and method of legal regulation, which are the determining criteria for the construction of the system of environmental law.

The system of natural resources law can be defined as an integrated and organized set of legal norms, which are interconnected by internal relations and regulate public relations on the use and reproduction of natural resources

48 Deineha M.A. Natural Resources Law: Problems of Formation and Development: Monograph / by general. ed. V.M. Yermolenko. Kyiv: NULES of Ukraine, 2019. P. 87. 
in their inextricable connection with other elements of the environment in order to meet the needs of human, society and state ${ }^{49}$.

\section{CONCLUSIONS}

The system of natural resource law is characterized by an internal organizational structure. It is objectively conditioned by natural resources relations its division into separate interrelated elements: legal norms, institutes, sub-branches. In addition, the structure of the natural resource law system can be represented by dividing it into general and special parts. The common part of natural resource law includes a number of legal institutions that contain norms of common law and are common to all types of natural resource relations that are subject to legal regulation. Institutions of the Common Law on Natural Resources include: ownership of natural resources; the right to use natural resources; legal regulation of reproduction of natural resources; legal support for management in the field of use and reproduction of natural resources; legal responsibility for violations of environmental legislation. The legal norms and institutions of a particular part regulate certain relatively separated groups of social relations and have a lesser degree of generality. The norms of these institutes are aimed at taking into account the peculiarities of different types of natural resource relations. Relations arising from the use of certain types of natural resources are governed by the rules included in the Special Part: Land Law; water law; forest law; subsoil right; floristic law; faunistic law.

At present, all objective prerequisites have been formed and there is every reason to argue for the formation of an independent branch of law - natural resource law, separation and separation of it from the environmental structure. The fundamental differences between environmental law and environmental law are reflected in the subject matter and object of the legal regulation, the method and its sources. Natural resources law regulates public relations, which consist of the use and reproduction of natural resources, while the subject of environmental (environmental) law is public relations concerning the protection of natural objects and the environment in general, internal and external relations, natural objects, their properties, states and processes occurring in them. The use of natural resources and the protection of the environment are different forms and forms of interaction between society and nature in their goals and objectives. The first is designed to meet the various needs of man and society, and the ultimate goal of protecting the environment is to achieve its quality.

49 Deineha M.A. Natural Resources Law: Problems of Formation and Development: Monograph / by general. ed. V.M. Yermolenko. Kyiv: NULES of Ukraine, 2019. P. 171. 
Natural resources law should be considered as an independent branch of law in the system of law of Ukraine, the legal rules of which regulate complex public relations on the use (extraction and consumption of useful properties) and reproduction (restoration of quantitative and qualitative characteristics) of natural resources that have potential or actual value for human beings and is the source of the necessary material and spiritual benefits.

\section{SUMMARY}

The section of the monograph is devoted to the research of scientific approaches to the formation of natural resources law, to find out the place of natural resources law in the legal system. The theoretical positions of representatives of legal science concerning the definition of the subject of legal regulation, peculiarities of nature-resource relations are revealed. The scientific approaches to the relation of natural resource law with environmental protection and environmental law are analyzed.

\section{REFERENCES}

1. Andreytsev V.I. Environmental law. General: Lecture Course in Schemes: Tutorial. Kyiv: Venturi, 1996. 208 p.

2. Andreytsev V.I. Prospects for the development of natural resource law in the system of environmental law of Ukraine. Natural Resources Law in the Law System of Ukraine: History, Present, Prospects: Collection of Round Table Materials (Kharkiv, October 30-31, 2015) / ed. M.V. Shulga. Kharkiv: Yaroslav the Wise National Law University, 2015. P. 9-15.

3. Bobylev A.K., Belashenko S.A. Questions of the theory of environmental law. Minsk, 1991. 203 p.

4. Vovk Yu.A. Soviet environmental law and environmental protection. The common part: a study guide. Kharkiv: High School, 1986. 317 p.

5. Deineha M.A. Natural Resources Law: Problems of Formation and Development: Monograph / by general. ed. V.M. Yermolenko. Kyiv: NULES of Ukraine, 2019. $340 \mathrm{p}$.

6. Deineha M.A. Problems of formation of natural resources law. Scientific Bulletin of the National University of Life and Environmental Sciences of Ukraine: Law series / ed.: S.M. Nikolaenko (chairman) and others. Kyiv, 2015. Vol. 232. P. 58-64.

7. Deineha M.A. Development of scientific thought on the formation of natural resources law. Scientific Bulletin of Uzhgorod National University. 2018. Issue No 49. P. 9-11.

8. Environmental Law of Ukraine. Academic course: textbook / ed. Yu.S. Shemshuchenko. 2nd edition. Kyiv: Legal Opinion, 2008. 848 p. 
9. Environmental Law: textbook / ed. A.P. Hetman. Kharkiv: Law, 2013. $272 \mathrm{p}$.

10. Erofeev B.V. Soviet natural resource law. Moscow: Law. 283 p.

11. Erofeev B.V. Environmental law: textbook. Moscow: The New Lawyer, 1998. 688 p.

12. Yermolenko V.M. Natural resources law in the system of law of Ukraine. Natural Resources Law in the Law System of Ukraine: History, Present, Prospects: Collection of Round Table Materials (Kharkiv, October 30-31, 2015) / ed. M.V. Shulga. Kharkiv: Yaroslav the Wise National Law University, 2015. P. 88-91.

13. Yermolenko V.M. Theoretical problems of differentiation of branches of environmental and natural resources law. Law of Ukraine. 2010. № 6. P. 348-351.

14. Kazantsev N.D. Natural resources law and its limits as an integrated sector. Bulletin of the Moscow University. 1967. № 6. P. 6-9.

15. Kalinin I.B. Natural resource law: training manual. Tomsk: Publishing House Tom. University, 2009. 350 p.

16. Karakash I.I. The subject and system of natural resource law. Natural resources law of Ukraine: textbook / ed. I.I. Karakash. Kiev: Truth, 2005. P. 5-41.

17. Karakash I.I. On the differentiated and integrated concept of natural resources and environmental law. Problems of integration and differentiation in environmental law: materials of the round table (Dnipropetrovsk, September 25, 2014). Dnepropetrovsk: NSU, 2014. P. 87-93.

18. Kolbasov O.S. Ecology: politics - law. Legal protection of nature in the USSR. Moscow: Science, 1976. 232 p.

19. Kostytsky V.V. Environmental law: textbook. Drohobych: The Circle, 2012. $360 \mathrm{p}$.

20. Krasnova M.V. Methodological principles of modern environmental law. Bulletin of Taras Shevchenko National University. Law. 2012. № 92. P. 5-8.

21. Krasnova M.V. Modern realities of the natural resource law of Ukraine. Natural Resources Law in the Law System of Ukraine: History, Present, Prospects: Collection of Round Table Materials (Kharkiv, October 30-31, 2015) / ed. M.V. Shulga. Kharkiv: Yaroslav the Wise National Law University, 2015. P. 143-146.

22. Krasnova Yu.A. Problems of integration and differentiation in environmental law: the issue of the formation of environmental security law. Problems of integration and differentiation in environmental law: materials of the Round Table (Dnipropetrovsk, September 25, 2014). P. 145-151. 
23. Kulinich P.F. Natural law as a legal phenomenon: polemical aspects. Natural Resources Law in the Law System of Ukraine: History, Present, Perspectives: Collection of Round Table Materials (Kharkiv, October 30-31, 2015) / in total. ed. M.V. Shulga. Kharkov: Issue of Oberg Ltd., 2015. P. 152-155.

24. Malysheva N., Nepyvoda V. Correlation of natural resource law and environmental law: a new look at the old problem. State and Law. No. 9. 2007. P. 31-40.

25. Markina N.A. Natural resource law: lecture course. Vitebsk: VSU named after P.M. Masherova, 2017. 49 p.

26. Mukhitdinov N.B. Fundamentals of mountain law: Some important points of theory and practice. Alma-Ata, 1983. $333 \mathrm{p}$.

27. Osipov N.T. Theoretical problems of Soviet land law. Leningrad: Publishing House of Leningrad State University, 1975. 320 p.

28. Pankratov I.F. Improving environmental and land law in modern conditions: materials of a scientific and practical conference. State and law. 1996. No. 5. P. 121-125.

29. Petrov V.V. The concept of environmental law as a legal community, science and academic discipline. Bulletin of Moscow University. Series 11. Law. 1987. No 5. P. 34-39.

30. Petrov V.V. Ecology and law. Moscow: "Legal literature", 1981. $224 \mathrm{p}$.

31.Popov V.K. Soviet natural resource law and legal environmental protection. A common part. Popov V.K., Vovk Yu.A. and other. Kharkov: Publishing house Khark. state University, 1988. 372 p.

32. Legal protection of nature / ed. V.V. Petrova. Moscow, 1980. $312 \mathrm{p}$.

33. Natural resources law of Ukraine: textbook / ed. I.I. Karakash. Kiev: The Truth, 2005. $376 \mathrm{p}$.

34. Natural resource law and legal environmental protection / ed. V.V. Petrova. Moscow: Jurid. lit., 1988. 421 p.

35. Razgeldeev N.T. Responsibility under the Soviet environmental law. Saratov: Publishing house of Sarat. University, 1986. 198 p.

36. Tyutekin Yu.I. Nature, society, law. Chisinau, 1971. 219 p.

37. Chubukov G.V. Natural resource law of the Russian Federation: textbook. Moscow: MGIU, 2007. 276 p.

38. Shemshuchenko Yu.S. Legal problems of ecology. Kiev: Naukova Dumka, 1989. 206 p.

39. Shulga M.V. Current legal problems of land relations in modern conditions. Kharkov: Consum, 1998. 224 p.

40. Yakovlev V.N. Environmental law: textbook. Chisinau, 1988. 344 p. 


\section{Information about the authors:}

Yermolenko V. M.,

Doctor of Law, Professor,

Head of the Academician V.Z. Yanchuk Department

of Agrarian, Land and Environmental Law,

National University of Life and Environmental Sciences of Ukraine

15, Heroiv Oborony str., Kyiv, 03041, Ukraine

ORCID: 0000-0002-4295-4158

ResearcherID: Y-1490-2018

Deineha M. A.,

Candidate of Law, Associate Professor,

Associate Professor of the Academician V.Z. Yanchuk Department of Agrarian, Land and Environmental Law, National University of Life and Environmental Sciences of Ukraine

15, Heroiv Oborony str., Kyiv, 03041, Ukraine

ORCID: 0000-0002-4785-7509

ResearcherID: Y-1361-2018

Kostytska I. O.,

Candidate of Law Sciences, Senior Researcher, Deputy Head of the Department of the Institute of Legislation,

Verkhovna Rada of Ukraine 5, Mykhaila Hrushevskoho str., Kyiv, 01008, Ukraine

ORCID: 0000-0003-2336-1426 